\title{
Forskrivning av antihypertensive legemidler 1975-2010
}

\begin{abstract}
Sammendrag
Bakgrunn. Noen samlet oversikt over medikamenter som brukes ved hypertensjon, er ikke tilgjengelig i offisielle datakilder. Målet med studien var å unders $\emptyset$ ke bruken av antihypertensiver over år for å identifisere trender i forbruksmønsteret.
\end{abstract}

Materiale og metode. Data ble hentet fra grossistbasert legemiddelstatistikk for årene 1975-2010 og fra Reseptregisteret for årene 2004-10. Definerte døgndoser (DDD) per 1000 innbyggere per døgn og antall og andel brukere av antihypertensiver, fordelt på kjønn og alder, ble registrert og analysert.

Resultater. I perioden 1975-2010 økte bruken av antihypertensiver fra 55 til 248 DDD/1 000 innbyggere/døgn, ifølge grossistbasert legemiddelstatistikk. Data fra Reseptregisteret viste at det $\mathrm{i}$ 2010 var totalt 754909 brukere av antihypertensiver, hvorav 638830 hadde diagnosen hypertensjon. Fra 2004 til 2010 var det størst økning i antall brukere av tiazider og angiotensin II-antagonister (All-antagonister). For dem under 73 år var andelen brukere av antihypertensiver i 2010 høyest blant menn, for dem som var enda eldre var andelen høyest blant kvinner.

Fortolkning. Bruken av antihypertensive legemidler er stadig økende. Allantagonister og tiazider er de mest benyttede medikamentene. Legemiddelmyndighetenes inngripen med tiazidvedtaket i 2004 bidro sannsynligvis til økt tiazidbruk.
Hege Salvesen Blix

hege.salvesen.blix@fhi.no

Avdeling for legemiddelepidemiologi

Nasjonalt folkehelseinstitutt

Knud Landmark

Farmakologisk institutt

Institutt for klinisk medisin

Universitetet i Oslo

Randi Selmer

Avdeling for legemiddelepidemiologi

Nasjonalt folkehelseinstitutt

Åsmund Reikvam

Farmakologisk institutt

Institutt for klinisk medisin

Universitetet i Oslo

Hypertensjon er utbredt i den norske befolkningen og utgjør sammen med røyking og forhøyet kolesterolnivå de klassiske risikofaktorer for hjerte- og karsykdom. Blodtrykksgrensene for definisjon av hypertensjon har variert over tid og er i dag lavere enn anbefalingene fra Norsk selskap for allmennmedisin (NSAM) fra 1980- og 90-årene $(1,2)$. Også internasjonale spesialistorganisasjoner har over tid anbefalt lavere hypertensjonsgrenser og lavere behandlingsmål $(3,4)$. I dag anbefales oppstart av antihypertensiv behandling etter en risikovurdering der andre faktorer som alder, kjønn, blodtrykk, kolesterolnivå og røyking inngår (5). Blodtrykk i relasjon til risiko for kardiovaskulær sykdom kan betraktes som et kontinuum der risikoen øker med økende blodtrykk. Både ikke-farmakologisk og farmakologisk behandling av hypertensjon vil redusere risikoen for kardiovaskulære hendelser.

I Norge har vi i utstrakt grad vært tidlig ute med å ta i bruk nye patentbeskyttede medikamenter og har opp gjennom årene hatt en annen og dyrere forbruksprofil når det gjelder antihypertensiver enn de andre nordiske land $(6,7)$. Legemiddelmyndighetene har ut fra økonomiske motiver tilkjennegitt at billigere, etablerte medikamenter burde brukes mer. Stortinget gjorde i 2004 endringer i refusjonskriteriene for blodtrykksmedisiner og iverksatte det såkalte tiazidvedtaket. Som betingelse for refusjon ble det forutsatt at tiazider var vurdert som førstevalg ved essensiell hypertensjon (8). Tiazidvedtaket ble opphevet 1.1. 2010, og det ble da åpnet for at et bredt utvalg av legemidler kunne forskrives som førstevalg (9). Grunnen til opphevelsen var at andre veletablerte midler hadde fătt akseptabel kostnadseffektivitet.

Kunnskap om forbruksutviklingen av antihypertensiver gir innsikt i legers forskrivningspraksis og er viktig for leger, helsemyndigheter og andre beslutningstakere $\mathrm{i}$ helsesektoren. Tiazider, betablokkere, kalsiumantagonister, angiotensinkonvertasehemmere (ACE-hemmere) og angiotensin II-antagonister (AII-antagonister) er anerkjente antihypertensiver. Men disse medikamentgruppene brukes på flere ulike indikasjoner, og den samlede medikamentbruken ved hypertensjon er derfor ikke tilgjengelig i offisiell statistikk $(10,11)$.

Målet med denne studien var å beskrive bruken av antihypertensiver gjennom de seneste tiår, med særlig søkelys på perioden 2004-10, for å identifisere og forstå trender i forbruksmønsteret.

\section{Materiale og metode}

To landsomfattende kilder gir informasjon om bruken av legemidler i den norske befolkningen - grossistbasert legemiddelstatistikk og Reseptregisteret $(10,11)$. Begge databasene er basert på salget av legemidler til henholdsvis apotek og pasienter. Selv om ikke alt salg av legemidler nødvendigvis innebærer at de er inntatt, vil salgsvolumet være et godt mål for legemiddelforbruket.

Grossistbasert legemiddelstatistikk gir informasjon om totalt salg av legemidler fra grossist til apotek. Data er tilgjengelig fra 1970-årene. Grossiststatistikken gir ingen informasjon om pasient eller forskrivende lege, men gir mulighet for å følge overordnet legemiddelbruk over tid. Informasjon om det totale salg av tiazider fra 1975 til 2010 ble hentet fra denne datakilden. Alle legemidler som inneholder tiazider er inkludert (tab 1). ATC-koder (anatomisk-terapeutisk-kjemisk) og definerte døgndoser (DDD) ble benyttet på hele datamaterialet (12). Definerte døgndoser for tiazider er basert på dagens anbefalte lavdosebehandling.

Fra Reseptregisteret ble det for årene 2004-10 innhentet opplysninger om kjønn, alder og dato for utlevering av antihyperten-

\section{Hovedbudskap}

- Bruken av antihypertensiver er firedoblet de siste 30 år

- All-antagonister og tiazider er i dag de mest brukte antihypertensiver

- Tiazidvedtaket i 2004 bidro sannsynligvis til økt tiazidbruk 


\section{DDD/1 000 innbyggere/døgn}

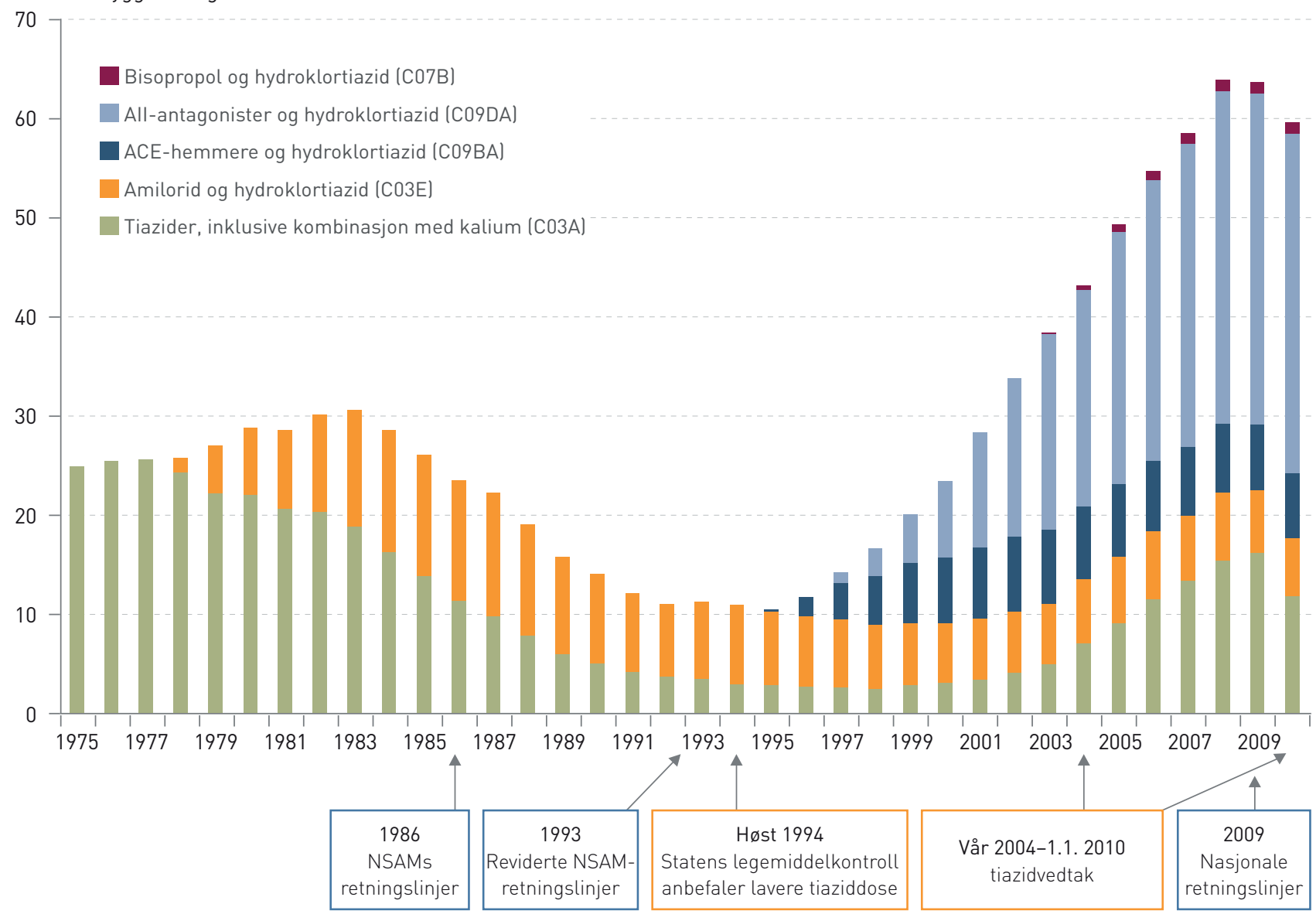

Figur 1 Bruk av tiazider i Norge, 1975-2010, presentert som akkumulert, ikke-individtilknyttet salg av legemidler i DDD/1 000 innbyggere/døgn lgrossistbasert legemiddelstatistikk).

Tabell 1 Definisjoner av brukere, antihypertensive legemidler, definert døgndose (DDD) og inkluderte diagnosekoder

\begin{tabular}{|c|c|}
\hline Bruker & En person, identifisert med løpenummer, som har hentet minst én resept på antihypertensiver i løpet av ett år \\
\hline Antihypertensiver & $\begin{array}{l}\text { Preparater i ATC-grupper: } \\
\text { - C02 antihypertensiver, unntatt doxazosin } \\
\text { - C03 diuretika, unntatt slyngediuretika (C03C) og aldosteronantagonister (C03D) } \\
\text { - C07 betablokkere, unntatt sotalol } \\
\text { - C08 kalsiumantagonister, unntatt nimodipin }\end{array}$ \\
\hline \multirow[t]{2}{*}{ Tiazider, enkle og i kombinasjon } & $\begin{array}{l}\text { Tiazider, enkle (ATC-gruppe: CO3A'): } \\
\text { - Bendroflumetiazid } \\
\text { - Hydroflumetiazid } \\
\text { - Hydroklortiazid } \\
\text { - Klortiazid } \\
\text { - Polytiazid } \\
\text { - Triklormetiazid }\end{array}$ \\
\hline & $\begin{array}{l}\text { Tiazider i kombinasjon med andre antihypertensive midler (ATC-grupper: C03E, C07B, C09B, C09DA, C09DX) } \\
\text { - Amilorid/tiazid (C03E) } \\
\text { - Bisoprolo/tiazid (C07B) } \\
\text { - ACE-hemmer/tiazid (CO9B) } \\
\text { - All-antagonist/tiazid (C09DA) }\end{array}$ \\
\hline DDD & $\begin{array}{l}\text { Definert døgndose = den gjennomsnittlige daglige vedlikeholdsdose } \\
\text { hos voksne for preparatets hovedindikasjon }\end{array}$ \\
\hline Diagnosekoder & $\begin{array}{l}\text { Følgende diagnosekoder er inkludert: } \\
\text { ICPC: Hypertensjon; ukomplisert (K86) og med komplikasjoner (K87) } \\
\text { ICD-10: Hypertensjon; primær (I10), sekundær (I15), hypertensiv hjerte- og nyresykdom (I11, I12, I13), } \\
\text { svangerskapshypertensjon }(010,011,013,014,016)\end{array}$ \\
\hline
\end{tabular}


siver samt følgende spesifikke informasjon om det enkelte legemiddel: generisk navn, produktnavn, ATC-kode og definerte døgndoser. Vi definerte antihypertensiver som legemidler som har hypertensjon som en av hovedindikasjonene (tab 1). For hvert alderstrinn ble andelen brukere (\%) av antihypertensiver i 2010 regnet ut. Medisiner utlevert til sykehjem og sykehus er ikke sporbare på individnivå og ble derfor ikke inkludert.

Antihypertensiver forskrives også på andre indikasjoner, som hjertesvikt og koronarsykdom. I Reseptregisterets første år kunne ikke bruk av et gitt medikament på ulike indikasjoner identifiseres, men i løpet av 2009 inngikk også diagnosekoder fra blåresepter. For perioden 1.1.-31.12. 2010 ble diagnosekoder for antihypertensiver hentet ut. Antall og andel brukere med diagnosekoden hypertensjon kunne dermed bestemmes. Denne informasjonen ble benyttet til å estimere andelen av det registrerte medikamentforbruket som ble brukt på indikasjonen hypertensjon forut for 2010. Estimatene vil være grove, ikke minst fordi det forutsettes at diagnosefordelingen $\mathrm{i}$ disse årene er den samme som i 2010.

\section{Resultater}

I 1975 ble det brukt i alt 55 DDD/1 000 innbyggere/døgn av antihypertensiver, mens det i 2010 ble brukt 248 DDD/1 000 innbyggere/døgn. Enkle tiazider og tiazider i kombinasjon med kalium dominerte blodtrykksbehandlingen i 1970-årene sammen med sulfonamider og betablokkere. I 1975 ble det brukt $25 \mathrm{DDD} / 1000$ innbyggere/døgn av tiazider, men forbruket falt i 1980-årene. Det laveste nivået for tiazider ble registrert $\mathrm{i}$ 1995, med 10 DDD/1 000 innbyggere/døgn (fig 1). Fra 1995 kom det en betydelig økning i forskrivning av tiazider, hovedsakelig i kombinasjon med andre antihypertensiver. Gjennomsnittlig årlig økning i $\mathrm{DDD} / 1000$ innbyggere/døgn var på $14 \% \mathrm{i}$ årene 1995-2009. Det var særlig bruken av kombinasjonspreparater som økte i årene før 2004. Etter 2004 økte bruken av alle tiazidpreparater, både enkle og kombinasjoner (fig 1). Reduksjonen i salg av tiazider etter 2008 var i hovedsak forårsaket av redusert bruk av enkle tiazider.

I 2010 var det totalt 754909 personer som brukte legemidler som benyttes som antihypertensiver. Av disse hadde 638830 dia- gnosen hypertensjon. Antall personer som bruker antihypertensiver økte for alle legemiddelgrupper fra 2004 til 2010, unntatt for antihypertensiver (C02), tiazider (C03A) og amilorid/hydroklortiazid (C03E) (fig 2). Totalt var det flest brukere av betablokkere, men litt under halvparten av betablokkerdosene ble forskrevet på annen indikasjon. I 2010 var det AII-antagonister som hyppigst ble forskrevet for hypertensjon.

Andelen definerte døgndoser av ulike legemiddelgrupper forskrevet med diagnosekode hypertensjon for 2010 er angitt $i$ tabell 2. Enkle tiazider, AII-antagonister, kalsiumantagonister og alle kombinasjonsprodukter med tiazider ble i all hovedsak forskrevet til hypertensjonspasienter, mens betablokkere og enkle ACE-hemmere i betydelig grad ble brukt på andre indikasjoner.

Andelen av befolkningen som fikk forskrevet antihypertensiver økte kraftig med økende alder frem til ca. 80 års alder, hvoretter bruken var fallende. Av dem som var i slutten av 70-årene, brukte i overkant av $50 \%$ medikamenter for hypertensjon. Til rundt 73 års alder var bruken høyest blant menn, mens det for dem $i$ aldersgruppen over

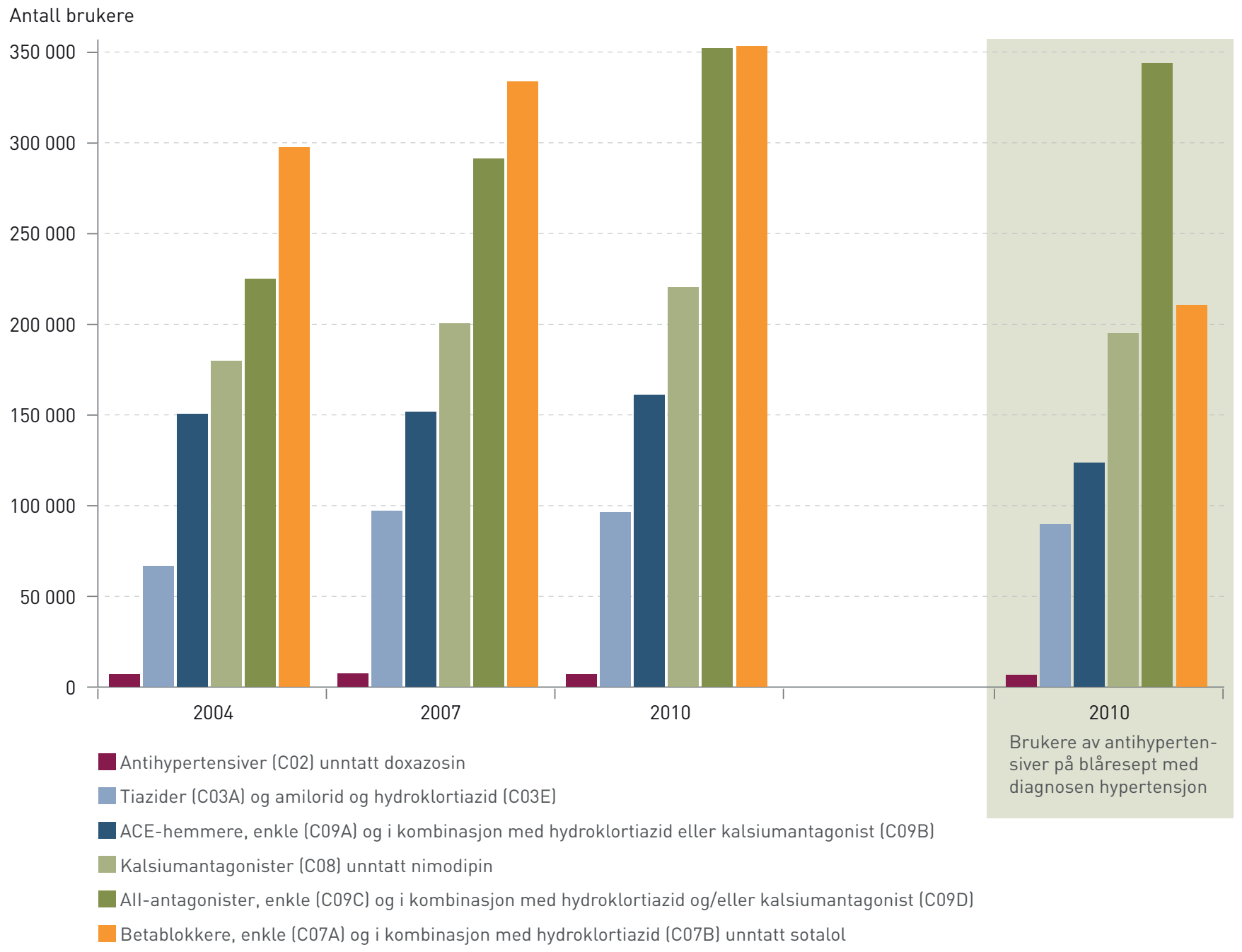

Figur 2 Antall brukere av legemidler som anvendes ved hypertensjon i Norge i 2004, 2007 og 2010 (brukere med andre indikasjoner enn hypertensjon er inkludert). Til høyre i ramme: Antall brukere av legemidler som er forskrevet på trygderesept (blåresept) med diagnosen hypertensjon i 2010 (reseptregisterdata). Ved bruk av flere typer antihypertensiver vil én enkelt person registreres som bruker flere ganger 
denne var høyest andel brukere blant kvinner. Etter 65 års alder fikk kvinner forskrevet markant mer tiazider enn menn (fig 3).

\section{Diskusjon}

Bruken av medikamenter som anvendes som antihypertensiver er nesten femdoblet på 30 år, målt i definerte døgndoser. Et grovt estimat med basis i diagnoseopplysninger fra 2010 indikerer at når andre indikasjoner enn hypertensjon ekskluderes, har det vært nær en firedobling i bruken av midler til behandling av hypertensjon i perioden (data ikke vist). Sannsynligvis skyldes den økte bruken en kombinasjon av bedre diagnostikk av hypertensjon, lavere hypertensjonsgrenser for oppstart av behandling og mer intensiv behandling med lavere behandlingsmål. Det sistnevnte innebærer også forskrivning av flere typer antihypertensiver til hver enkelt pasient. Tidligere norske studier har vist underbehandling av pasienter med hypertensjon (13), og økningen i bruk av antihypertensiver kan bety at befolkningen nå får bedre behandling.

Tradisjonelt har tiazider vært basismedikamenter ved behandling av hypertensjon, men bruken ble gradvis redusert til en tredel fra midten av 1980-årene til 1990-årene. Ved vurdering av denne observasjonen må det tas hensyn til at den internasjonalt fastsatte definerte døgndose for tiazider ble redusert i 1996, fordi det i praksis etter hvert var blitt vanlig å bruke lavere doser. Eksempelvis ble

Tabell 2 DDD/1 000 innbyggere/døgn brukt i Norge i 2010 og andel (\% av totalt antall DDD) som er forskrevet med diagnosekoder hypertensjon i 2010 (data fra Reseptregisteret)

\begin{tabular}{llcc} 
ATC & Legemiddelgruppe & $\begin{array}{c}\text { DDD/1 000 } \\
\text { innbyggere/døgn }\end{array}$ & $\begin{array}{c}\text { Andel DDD } \\
\text { med diagnose } \\
\text { hypertensjon (\%) }\end{array}$ \\
C02 & Antihypertensiver, eksklusive doxazosin & 1,3 & 96,3 \\
\hline C03A & Tiazider, enkle & 11,9 & 91,4 \\
\hline C03E & Amilorid og hydroklortiazid & 5,8 & 92,8 \\
C07A & Betablokkere, eksklusive sotalol & 36,9 & 59,6 \\
\hline C07B & Bisoprolol og hydroklortiazid & 1,1 & 99,8 \\
C08 & Kalsiumantagonister, eksklusive nimodipin & 55,3 & 88,4 \\
C09A & ACE-hemmere & 44,3 & 62,2 \\
C09BA & ACE-hemmere og hydroklortiazid & 6,5 & 99,7 \\
C09BB & ACE-hemmere og kalsiumantagonister & 0,1 & 99,5 \\
\hline C09C & All-antagonister & 43,9 & 95,1 \\
C09DA & All-antagonister og hydroklortiazid & 33,8 & 99,8 \\
\hline C09DB & All-antagonister og kalsiumantagonister & 2,7 & 99,9 \\
\hline C09DX & All-antagonister, hydroklortiazid og kalsium- & & $9,9,9$ \\
& antagonist & 0,4 & \\
\hline & & & \\
\hline
\end{tabular}

definert døgndose for hydroklortiazid redusert fra $50 \mathrm{mg}$ til $25 \mathrm{mg}$ (14). Alle våre retrospektive beregninger er basert på dagens definerte døgndose. Dette betyr at utbredelse av tiazidbruk i befolkningen (målt i definerte døgndoser) overestimeres for perioden da høyere doser var vanlig. Men selv om det tas hensyn til dette forhold, er den observerte nedgangen så stor at det må være uttrykk for en reell reduksjon i antallet brukere fra 1980til 90-årene. Redusert tiazidbruk kan ha ulike årsaker, som økt oppmerksomhet omkring tiazidenes metabolske bivirkninger, samtidig som nye medikamentgrupper som kalsiumantagonister, ACE-hemmere og AII-antagonister ble tilgjengelige og aktivt markedsført.

I annen halvdel av 1990-årene begynte tiazidene å komme tilbake og fikk en styrket

Andel (\%) per alderstrinn som får antihypertensiver på blåresept med diagnosen hypertensjon i 2010

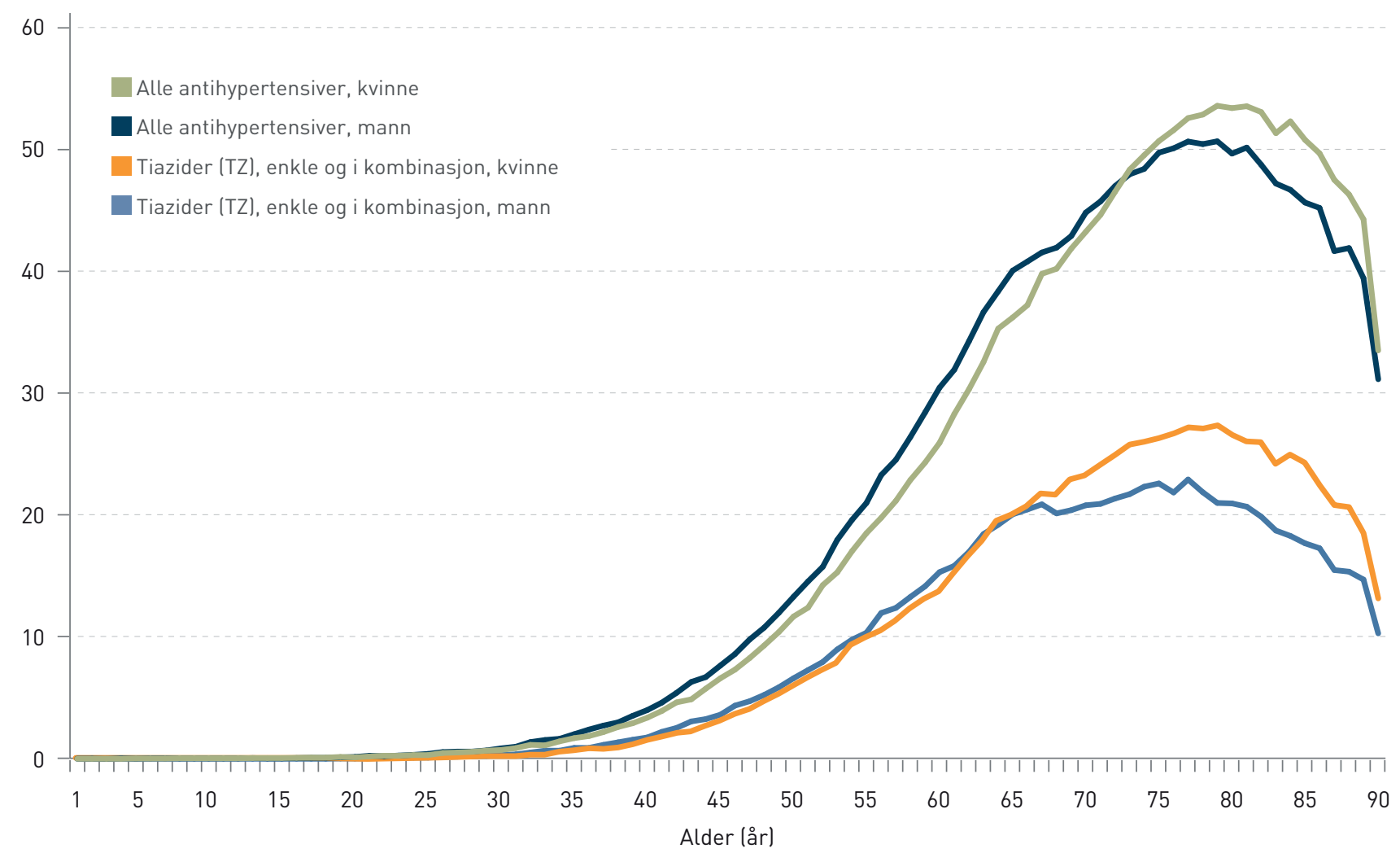

Figur 3 Andel i befolkningen fordelt på kjønn og alder som får antihypertensiver på blåresept med diagnosen hypertensjon i 2010 . Kurver for alle antihypertensiver, tiazider (TZ), enkle og i kombinasjon med andre antihypertensiver (reseptregisterdata) 
posisjon, delvis som enkeltmedikament, men hovedsakelig i kombinasjon med AIIantagonister og i noen grad med ACE-hemmere. Bruken av tiazider alene eller i kombinasjon med andre medikamenter (målt $\mathrm{i}$ definerte døgndoser) ble seksdoblet fra midten av 1990-årene til 2009.

Et særlig interessant spørsmål er om og eventuelt i hvilken grad tiazidvedtaket fra 2004 innvirket på forbruksmønsteret. Økningen i bruken av tiazider, særlig i kombinasjonspreparater med hemmere av reninangiotensin-systemet, var i gang før 2004, og kurven for bruk av tiazider viser ikke noe markert knekkpunkt. Dog var det for enkle tiazider en mer uttalt økning $\mathrm{i}$ årene etter 2004. Dette er forenlig med en viss effekt av tiazidvedtaket, noe som også var konklusjonen i en studie av forskrivningspraksis blant allmennleger i Oslo-området (15). At bruken av tiazider ble redusert fra 2009 til 2010 - en nedgang som i tid faller sammen med opphevelsen av tiazidvedtaket 1.1.2010 - er også en indikasjon på en kausal sammenheng mellom vedtaket og økt bruk av disse midlene i årene etter 2004.

Økt tillit til og økt bruk av tiazider allerede tidlig i tiåret etter 2000 kan trolig også tilskrives at man på dette tidspunktet hadde fått resultatene fra en rekke store kontrollerte kliniske forsøk der man sammenliknet tiazider og betablokkere med nyere medikamenter. Gjennomgående var de undersøkte medikamentene like effektive $\mathrm{i}$ å forebygge kardiovaskulære hendelser (16-20). Ikke minst ble ALLHAT-studien, hvor tiazider kom godt ut, viet mye oppmerksomhet (20). At tiazider ble anbefalt som førstehåndsmiddel i viktige internasjonale retningslinjer hadde nok også betydning for legenes forskrivning $(3,4)$.

En studie fra 2006 viste at på verdensbasis er ACE-hemmere mest brukt for hypertensjon, fulgt av betablokkere og AII-antagonister (21). Våre funn viser at blant personer med hypertensjon er det flest brukere av AII-antagonister (enkle og i kombinasjon med tiazider). Ikke minst ved oppstart av ny antihypertensiv behandling velges nå AIIantagonister eller tiazider (data ikke vist).

De to andre mest brukte legemiddelgruppene $\mathrm{i}$ behandlingen av hypertensjon er betablokkere og kalsiumantagonister. Betablokkerne er hyppigst brukt, men når man tar diagnoseopplysningene fra Reseptregisteret $\mathrm{i}$ betraktning, viser det seg at bare vel halvparten av betablokkerdosene forskrives for hypertensjon. Estimater for utviklingen i årene 2004-09 - med basis i diagnoseopplysningene fra 2010 - viser at antall brukere av kalsiumantagonister har økt, mens færre bruker betablokkere. Dette kan ha sammenheng med at det har vært satt spørsmålstegn ved betablokkernes effektivitet, $i$ første rekke atenolol, som tidligere var den mest brukte (22).

Våre nyeste funn for 2010 gir innblikk i kjønnsforskjeller når det gjelder behandling av hypertensjon. I aldersgrupper opp til ca. 73 år er det høyere andel menn enn kvinner som får behandling på indikasjonen hypertensjon, mens det $\mathrm{i}$ høyere alder er klart høyest andel kvinner som behandles. Det har vært antydet at kvinner over 75 år har høyere systolisk blodtrykk enn jevnaldrende menn (23), noe som kan være en forklaring på denne observasjonen. Det er verdt å merke at kvinner i høyere grad enn menn får forskrevet tiazider. Dette er også funnet av andre (21), men grunnen er ikke avklart. Komorbiditet kan ha hatt betydning for valg av medikament. Forskjellen i medikamentell behandling kan derfor avspeile det forhold at sykdomsbildet er forskjellig for de to kjønn, og gjerne mer komplisert hos menn, med høyere forekomst av koronar hjertesykdom og hjertesvikt

\section{Hege Salvesen Blix (f. 1957)}

er farmasøyt, spesialist i sykehusfarmasi og ph.d. Hun er seniorrådgiver ved Avdeling for legemiddelepidemiologi, Nasjonalt folkehelseinstitutt, og professor II ved Farmasøytisk institutt, Universitetet i Oslo.

Forfatter har fylt ut ICMJE-skjemaet og oppgir ingen interessekonflikter.

\section{Knud Landmark (f. 1931)}

er dr.med. og spesialist i indremedisin og hjertesykdommer. Han er professor emeritus ved Farmakologisk institutt, Universitetet i Oslo. Forfatter har fylt ut ICMJE-skjemaet og oppgir ingen interessekonflikter.

\section{Randi Selmer (f. 1953)}

er statistiker, epidemiolog og dr.philos. Hun er seniorforsker ved Avdeling for legemiddelepidemiologi, Nasjonalt folkehelseinstitutt.

Forfatter har fylt ut ICMJE-skjemaet og oppgir ingen interessekonflikter.

\section{Åsmund Reikvam (f. 1944)}

er professor ved Farmakologisk institutt/Institutt for klinisk medisin, Det medisinske fakultet, Universitetet i Oslo, og spesialist i indremedisin og hjertesykdommer

Forfatter har fylt ut ICMJE-skjemaet og oppgir ingen interessekonflikter.

\section{Litteratur}

Holmen J, Forsdahl A, Kvamme Jl et al. Høyt blod trykk. NSAMs handlingsprogram for allmennprak sis. Rapport 11. Oslo: Gruppe for helsetjenesteeffektivisering, 1986

2. Holmen J, Aursnes I, Forsdahl A et al. Høyt blodtrykk. NSAMs handlingsprogram. Rapport U3, 1993. Verdal: Samfunnsmedisinsk forskningssenter, Folkehelsa, 1993

3. Mancia G. De Backer G. Dominiczak A et al. 2007 ESH-ESC practice guidelines for the management of arterial hypertension: ESH-ESC task force on the management of arterial hypertension. J Hypertens 2007: 25: $1751-62$

4. Chobanian AV, Bakris GL, Black HR et al. The seventh report of the joint national committee on prevention, detection, evaluation, and treat ment of high blood pressure: the JNC 7 report. JAMA 2003: 289: 2560-72.

5. Helsedirektoratet. Nasjonale retningslinjer for individuell primærforebygging av hjerte- og kar sykdommer. IS-1550. www. helsedirektoratet.no (9.2.2012).

6. Medicines consumption in the Nordic countries 1999-2003. København: Nordic Medico-Statistica Committee, NOMESCO, 2004.

7. Fretheim A, Oxman AD. International variation in prescribing antihypertensive drugs: its extent and possible explanations. BMC Health Serv Res 2005 5: 21

8. Statens legemiddelverk. Tiazid som førstevalg ved hypertensjon. Nytt om legemidler 2004; nr. 2: 6.

9. Statens legemiddelverk. Vedtak: Endring i refusjonsvilkår for blodtrykksenkende midler, forskrift av 28. juni $2007 \mathrm{nr} 814,10$. desember 2009. Oslo: Statens legemiddelverk, 2009

10. Legemiddelforbruket i Norge 2004-2010. Lege middelstatistikk 2011: 1. Oslo: Nasjonalt folkehelseinstitutt, 2011

11. Reseptregisteret 2004-2010. www.reseptregisteret.no/ (9.2.2012)

12. WHO Collaborating Centre for Drug Statistics Methodology. ATC index with DDDs 2011. Oslo: WHO Collaborating Centre, Oslo, 2010.

13. Hetlevik I, Holmen J, Krüger 0 et al. Fifteen years with clinical guidelines in the treatment of hyper tension - still discrepancies between intentions and practice. Scand J Prim Health Care 1997; 15: $134-40$.

14. WHO Collaborating Centre for Drug Statistics Methodology. www.whocc.no/ (9.2.2012).

15. Fretheim A, Håvelsrud K, MacLennan $G$ et al. The effects of mandatory prescribing of thiazides for newly treated, uncomplicated hypertension: interrupted time-series analysis. PLoS Med 2007; 4 e232

16. Hansson L, Lindholm LH, Ekbom $T$ et al. Randomised trial of old and new antihypertensive drugs in elderly patients: cardiovascular mortality and morbidity the Swedish Trial in Old Patients with Hypertension-2 study. Lancet 1999: 354: 1751-6.

17. Hansson L, Lindholm LH, Niskanen L et al. Effect of angiotensin-converting-enzyme inhibition compared with conventional therapy on cardiovascula morbidity and mortality in hypertension: the Captopril Prevention Project (CAPPP) randomised trial. Lancet 1999: 353: 611-6.

18. Hansson L, Hedner T, Lund-Johansen P et al. Randomised trial of effects of calcium antagonists compared with diuretics and beta-blockers on cardiovascular morbidity and mortality in hypertension: the Nordic Diltiazem (NORDIL) study. Lancet 2000; 356: 359-65.

19. Dahlöf B, Sever PS, Poulter NR et al. Prevention of cardiovascular events with an antihypertensive regimen of amlodipine adding perindopril as required versus atenolol adding bendroflumethiazide as required, in the Anglo-Scandinavian Cardiac Outcomes Trial-Blood Pressure Lowering Arm (ASCOT-BPLA): a multicentre randomised controlled trial. Lancet 2005: 366: 895-906.

20. ALLHAT Officers and Coordinators for the ALLHA Collaborative Research Group. The Antihypertensive and Lipid-Lowering Treatment to Prevent Heart Attack Trial. Major outcomes in high-risk hypertensive patients randomized to angiotensinconverting enzyme inhibitor or calcium channel blocker vs diuretic: The Antihypertensive and Lipid-Lowering Treatment to Prevent Heart Attack Trial (ALLHAT). JAMA 2002: 288: 2981-97.

21. Thoenes M, Neuberger HR, Volpe M et al. Antihypertensive drug therapy and blood pressure control in men and women: an international perspective. J Hum Hypertens 2010; 24: 336-44.

22. Carlberg B, Samuelsson O, Lindholm LH. Atenolo in hypertension: is it a wise choice? Lancet 2004; 364: $1684-9$

23. Graff-Iversen S, Jenum AK, Grøtvedt L et al. Risikofaktorer for hierteinfarkt hierneslag og diabetes i Norge. Tidsskr Nor Lægeforen 2007; 127: 2537-41.

Mottatt 14.9. 2011, første revisjon innsendt 12.1. 2012, godkjent 9.2. 2012. Medisinsk redaktør Petter Gjersvik. 